DOI: http://dx.doi.org/10.24818/jamis.2020.03002

\title{
The influences on Activity-Based Costing adoption as an optimal costing system design: Evidence from Saudi Arabia
}

\author{
Abdulrahman Aljabr ${ }^{1, \mathrm{a}}$ \\ ${ }^{a}$ King Faisal University, Saudi Arabia
}

\begin{abstract}
Research Question: Under which conditions is the adoption of activity-based costing (ABC) beneficial to the business-unit and, hence, represents the optimal costing system design (CSD)?

Motivation: Identifying the situations under which $\mathrm{ABC}$ is beneficial with regard to the performance of the business-unit and, thus, represents the optimal CSD is important in order to make a correct decision to invest in ABC. This necessitates the adoption of the matching form of fit when examining the relationship between the influential factors and $\mathrm{ABC}$ adoption as an optimal CSD due to its ability to reflect when $\mathrm{ABC}$ is beneficial and, therefore, indicate the optimal CSD. This study builds on Ittner et al. (2002) to examine this relationship from the standpoint of the matching form of fit, and also extends this line of research by examining the effect of the most key influential factors, using a sufficiently comprehensive multi-dimensional production complexity (PC) measure.

Idea: This paper examines the role of the key influential factors on $\mathrm{ABC}$ adoption as an optimal CSD from the standpoint of the matching form of fit, using a sufficiently comprehensive multi-dimensional PC measure.

Data: The data were collected from 200 Saudi manufacturing business-units.

Tools: The questionnaire survey strategy was used to collect the data, which were then analysed using the residual analysis (RA) technique.

Findings: Unexpectedly, the results of the RA showed that none of the examined key factors of competition, indirect costs, PC and information technology quality (IT quality) affects $\mathrm{ABC}$ adoption as an optimal CSD from the viewpoint of the matching form of fit.

Contribution: This research contributes to the $\mathrm{ABC}$ adoption research by examining the situations under which $\mathrm{ABC}$ is beneficial and, hence, represents the optimal CSD through examining the impact of the key influential factors on $\mathrm{ABC}$ adoption as an optimal CSD from the standpoint of the matching form of fit.
\end{abstract}

1 Corresponding author: School of Business, King Faisal University, P.O. Box: 400, 31982, Al-Hasaa, Saudi Arabia, Tel: +966-13-5896124, email addresses: aaljabr@kfu.edu.sa.

Funding: The author acknowledges the Deanship of Scientific Research at King Faisal University for the financial support under Nasher Track (Grant No. 186159). 
Keywords: optimal costing system design (CSD), activity-based costing (ABC), contingency theory, matching form of fit, residual analysis.

JEL codes: M410

\section{Introduction}

Activity-based costing ( $\mathrm{ABC}$ ) proponents have emphasised that, to obtain the benefits of $\mathrm{ABC}, \mathrm{ABC}$ should be the optimal costing system design (CSD) with respect to the assignment of indirect costs to products (Cooper, 1988b; Cooper, 1989b; Kaplan \& Cooper, 1998). The optimal CSD is one that balances the cost of measurement required by the CSD and the cost of error resulting from poor decision-making based on distorted product costs (Cooper, 1988b; Kaplan \& Cooper, 1998; Stuart, 2013; Drury, 2018). It represents a point where the marginal costs and benefits of improving the CSD by increasing its complexity, in relation to the assignment of indirect costs to products, are equal, and where any excess or shortages related to improving the CSD would lower its optimisation (Cooper, 1988b). Having a more complex than required costing system, where the cost of measurement exceeds the cost of error, or a less complex than required costing system, where the cost of error exceeds the cost of measurement, is harmful to the performance of the business-unit (Cooper \& Kaplan, 1991; Cooper, 1989b; Stuart, 2013; Ittner et al., 2002; Pizzini, 2006). This indicates that the relationship between CSD and the outcome representing CSD optimality, e.g., financial performance, is curvilinear. In addition, $\mathrm{ABC}$ proponents have pointed out that the cost of the measurement-related factor - represented by the quality of the information technology (IT quality) - and cost of error-related factors - represented by the level of competition, the level of indirect costs and production complexity (PC) of which the product diversity dimension is intensively cited - affect the optimal CSD (Kaplan \& Cooper, 1998; Cooper, 1988b; Drury, 2018; Stuart, 2013). The way in which the ABC proponents have explained the optimal CSD - which beneficial $\mathrm{ABC}$ should represent - and the factors affecting it, suggest that the relationship between these factors and $\mathrm{ABC}$ adoption as an optimal CSD is in accordance with the matching form of fit of contingency theory. The matching form of fit assumes that the relationship between CSD and the outcome representing its optimality is curvilinear and impacted by the contingency factors (Burkert et al., 2014).

It is important to examine the relationship between the influential factors and $\mathrm{ABC}$ adoption as the optimal CSD from the standpoint of the matching form of fit in order to identify the situations under which $A B C$ is beneficial and represents the optimal CSD, which subsequently aids in making a correct decision to invest in ABC. Despite its importance, only Ittner et al. (2002) examined the relationship

Vol. 19, No. 3 
between one influential factor, which was the plant operational characteristics related to $\mathrm{PC}$, and $\mathrm{ABC}$ adoption as an optimal CSD from the standpoint of the matching form of fit. Nevertheless, the study suffered from two limitations. First, it examined the effect of only a single factor despite the existence of other key influential factors, such as the level of competition, indirect costs, and IT quality. Second, it employed a limited measure of PC, although more comprehensive measures can be utilised.

Given: (1) the importance of identifying the situations under which $\mathrm{ABC}$ is beneficial and, hence, represents the optimal CSD to make a correct decision regarding investing in $\mathrm{ABC}$; and (2) the limitations of Ittner et al. (2002) regarding the number of examined contingency factors and measurement of PC, the aim of this paper is to examine the influence of the key contingency factors, namely the level of competition, the level of indirect costs, PC and IT quality, on ABC adoption as an optimal CSD from the standpoint of the matching form of fit, using a sufficiently comprehensive multi-dimensional PC measure. Using questionnaire data collected from Saudi manufacturing business-units, the residual analysis (RA) results showed that none of the examined key factors affects $\mathrm{ABC}$ adoption as an optimal CSD from the viewpoint of the matching form of fit. This research contributes to the existing literature on $\mathrm{ABC}$ adoption research by examining the situations under which $\mathrm{ABC}$ is beneficial and, hence, represents the optimal CSD through testing the effect of the key influential factors on ABC adoption as an optimal CSD from the standpoint of the matching form of fit, using a sufficiently comprehensive multi-dimensional PC measure.

The remainder of this paper is organised as follows. Section 2 reviews the relevant literature and highlights the research gaps and opportunities. Section 3 develops hypotheses related to the effect of the cost of error-related and the cost of measurement-related factors on $\mathrm{ABC}$ adoption as an optimal CSD from the standpoint of the matching form of fit. Section 4 explains the research methodology and methods. Section 5 provides the results of this research. Section 6 discusses these results and concludes this paper.

\section{Literature review}

The underlying assumption of the matching form of fit is that the relationship between CSD and the outcome representing its optimality is curvilinear and affected by the contingency factors (Burkert et al., 2014; Chenhall \& Chapman, 2006). This assumption indicates that, at any level of the contingency factor, there is only one CSD level that provides the maximum outcome level - i.e., the optimal CSD level - and that any deviation - i.e., a misfit - from this CSD level reduces the outcome (Schoonhoven, 1981; Donaldson, 2001; Chenhall \& Chapman, 2006; Meilich, 2006; Gerdin \& Greve, 2008; Burkert et al., 2014). In other words, a fit is 
achieved and the outcome is maximised when there exists a match between the levels of the contingency factor and the CSD (Klaas \& Donaldson, 2009; Burkert et al., 2014). In contrast, a misfit is attained and the outcome is reduced when there exists a mismatch between the two (Chenhall \& Chapman, 2006; Klaas \& Donaldson, 2009; Burkert et al., 2014). Misfit can be in the form of an over-fit, where the CSD level exceeds the required level by the contingency factor, or an under-fit, where the CSD level is below the level required by the contingency factor (Donaldson, 2001; Meilich, 2006; Klaas \& Donaldson, 2009). Given the above, examining the relationship between the contingency factor and the optimal CSD from the perspective of the matching form of fit entails examining: (1) the direction of the association between the contingency factor and optimal CSD; and (2) the magnitude and sign of the impact of a misfit between both on the outcome. When both: (1) the direction of the association between the contingency factor and the optimal CSD; and (2) the magnitude and sign of the impact of the misfit on the outcome conform to expectations, there exists support for the hypothesised effect of the contingency factor on the optimal CSD from the perspective of the matching form of fit.

As mentioned in Section 1, it is crucial to investigate the relationship between the influential factors and $\mathrm{ABC}$ adoption as an optimal CSD from the standpoint of the matching form of fit to identify the situations under which $\mathrm{ABC}$ is beneficial and represents the optimal $\mathrm{CSD}$, which afterwards assists when making decisions regarding investment in $\mathrm{ABC}$. Despite the importance of utilising the matching form of fit, most studies have utilised the selection form of fit (e.g., Bjørnenak, 1997; Gosselin, 1997; Malmi, 1999; Al-Mulhem, 2002; Brown et al., 2004; Kallunki \& Silvola, 2008; Schoute, 2011; Jusoh \& Miryazdi, 2016), which models the relationship between the contingency factor and $\mathrm{ABC}$ adoption as an optimal $\mathrm{CSD}$ as an association between the contingency factors and $\mathrm{ABC}$ adoption without incorporating any outcome variable that represents the optimality of ABC (Gerdin \& Greve, 2004; Hartmann, 2005). This is known as the equilibrium assumption (Chenhall \& Chapman, 2006; Meilich, 2006; Burkert et al., 2014). Other studies have used the moderation form of fit (e.g., Frey \& Gordon, 1999; Cagwin \& Bouwman, 2002; Elhamma, 2012; Elhamma \& Zhang, 2013; Krumwiede \& Charles, 2014; Maiga et al., 2014), which models the relationship between the contingency factors and $\mathrm{ABC}$ adoption as an optimal CSD as a linear rather than a curvilinear association between CSD and the outcome representing its optimality, with the contingency factors affecting this linear relationship (Meilich, 2006; Gerdin \& Greve, 2008; Burkert et al., 2014). ${ }^{2}$

Only Ittner et al. (2002) examined the relationship between one influential factor, which was the plant operational characteristics related to $\mathrm{PC}$, on $\mathrm{ABC}$ adoption as an optimal CSD from the standpoint of the matching form of fit. The study found that plant operational characteristics related to PC had a weak positive effect on 
$\mathrm{ABC}$ adoption as an optimal CSD from the viewpoint of the matching form of fit. In particular, Ittner et al. (2002) found that the plant operational characteristics related to $\mathrm{PC}$ factor is positively associated with $\mathrm{ABC}$ adoption as an optimal CSD, but that only an over-fit has a weak negative effect on financial performance that represents the optimality of ABC. Despite the study's originality, it has two limitations. First, it examined the effect of only a single cost of error-related factor, namely plant operational characteristics related to $\mathrm{PC}$, on $\mathrm{ABC}$ adoption as an optimal CSD from the perspective of the matching form of fit. It is necessary to identify how other predominant cost of error-related factors - namely the level of competition and indirect costs - and the main cost of measurement-related factor, namely IT quality, affect ABC adoption as an optimal CSD from the perspective of the matching form of fit. This is because the prior literature emphasised that, in addition to PC, these factors also influence ABC adoption as an optimal CSD (Cooper, 1988b; Kaplan \& Cooper, 1998). Examining the impact of these factors will provide a clearer insight regarding the situations under which adopting $\mathrm{ABC}$ is beneficial. Second, Ittner et al. (2002) used a limited measure of PC. Specifically, the study did not use a sufficiently comprehensive multi-dimensional PC measure. Rather, Ittner et al. (2002) used separate constructs that, in total, covered the three PC dimensions of production type, product diversity and the frequency of introducing new products. Prior research suggested that there are many PC dimensions, such as product customisation (e.g., Bjørnenak, 1997; Brierley, 2011), product complexity (Swenson, 1998), product diversity (Cooper, 1988b), the frequency of introducing new products (Nguyen \& Brooks, 1997), the frequency of making changes to products and manufacturing processes (Cagwin \& Bouwman, 2002) and the production period of products (Duh et al., 2009). Using a sufficiently comprehensive multi-dimensional PC measure is crucial in order to identify correctly the true effect of $\mathrm{PC}$ on $\mathrm{ABC}$ adoption as an optimal CSD from the standpoint of the matching form of fit.

Both (1) the importance of identifying the situations under which $A B C$ is beneficial and, hence, represents the optimal CSD to make a correct decision in investing in $\mathrm{ABC}$; and (2) the limitations of Ittner et al. (2002) encourage further research to examine the impact of the key contingency factors, namely the level of competition, the level of indirect costs, PC and IT quality, on ABC adoption as an optimal CSD from the standpoint of the matching form of fit, using a sufficiently comprehensive multi-dimensional PC measure.

\section{Hypotheses development}

The hypotheses developed in this section are related to the effect of the cost of error-related factors - namely the level of competition, indirect costs and PC - and the cost of measurement-related factor, namely IT quality, on $\mathrm{ABC}$ adoption as an optimal CSD from the perspective of the matching form of fit. With respect to the 
cost of error-related factors, the $\mathrm{ABC}$ adoption research has suggested that the level of competition, the level of indirect costs and $\mathrm{PC}$ positively affect $\mathrm{ABC}$ adoption (e.g., Cooper, 1988b; Kaplan \& Cooper, 1998; Bjørnenak, 1997; Malmi, 1999; AlOmiri \& Drury, 2007). This is due to the association between these factors, the cost of error and CSD (Cooper, 1988b). The risk of competitors being able to exploit any errors made by the business-unit and, hence, the danger of reducing the business-unit's profitability is enhanced when the level of competition is high (Cooper, 1988b; Cooper \& Kaplan, 1991). Thus, in highly competitive environments, $\mathrm{ABC}$ is needed, owing to its ability to assign indirect costs to products more precisely than traditional costing systems (TCSs) and, therefore, decrease the number of errors (Cooper \& Kaplan, 1991; Bjørnenak, 1997; Malmi, 1999). Ultimately, ABC adoption in highly competitive environments contributes towards reducing the competitors' opportunity to benefit from erroneous decisions made by the business-unit based on inaccurate costs (ibid).

When the levels of indirect costs and PC are high and TCS is being used, the possibility of reporting distorted product costs and, thus, the cost of error are likely to be high (Cooper, 1988b; Kaplan \& Cooper, 1998; Booth \& Giacobbe, 1998; Nguyen \& Brooks, 1997). High levels of indirect costs increase the chance of having costs at various levels - i.e., the unit, batch, product and facility levels most of which cannot be accurately assigned to products by TCS (Cooper, 1990). High levels of PC suggest that the amount of resources consumption is highly likely to vary between products and that the amount of batch- and product-level costs is likely to increase (Cooper, 1988a; 1988b; 1989a; Estrin et al., 1994; Kaplan \& Cooper, 1998; Swenson, 1998; Al-Omiri \& Drury, 2007; Schoute, 2011). Accordingly, $\mathrm{ABC}$ would be the optimum choice in high indirect cost and $\mathrm{PC}$ environments, given that $\mathrm{ABC}$ uses a large number of activity-based cost pools and volume- and non-volume-based cost drivers and, thus, is capable of accounting for resource consumption variations and accurately assigning most levels of indirect costs to products. In contrast, when the levels of indirect costs and PC are low, using TCS is not harmful because TCS causes minimal or no product cost distortion and therefore low or no errors, respectively (Nguyen \& Brooks, 1997; Booth \& Giacobbe, 1998; Kaplan \& Cooper, 1998; Brierley et al., 2001; Charaf \& Bescos, 2013). Thus, adopting $\mathrm{ABC}$ in such environments is less likely to add value and may, when the levels of indirect costs and PC are extremely low, be harmful because of the over-investment in the CSD (Kaplan \& Cooper, 1998; Stuart, 2013).

The empirical evidence has provided inconsistent results regarding the effect of the level of competition, indirect costs and $\mathrm{PC}$ on $\mathrm{ABC}$ adoption. Several studies have found, as suggested by $A B C$ theory, positive effects of these factors on $A B C$ adoption, while others have not or even found negative effects (for example, see the mixed results of Bjørnenak, 1997; Nguyen \& Brooks, 1997; Booth \& Giacobbe, 1998; Malmi, 1999; Chen et al., 2001; Cohen et al., 2005; Al-Omiri \& 
Drury, 2007; 2013; Brierley, 2011; Jusoh \& Miryazdi, 2016; Pokorná, 2015). These inconsistent findings may have been due to, for example, the differences between studies in relation to the definitions utilised for $\mathrm{ABC}$ adoption and nonadoption, the measurements used for the factors, the adopted statistical analysis techniques and the selected samples. Nevertheless, the theory asserts the positive influences of these factors on $\mathrm{ABC}$ adoption. The positive association between each of the level of competition, indirect costs and $\mathrm{PC}$ and $\mathrm{ABC}$ adoption indicates the fit between each contingency factor and $\mathrm{ABC}$ adoption that provides the highest level of the outcomes reflecting CSD optimality. This suggests a positive relationship between each factor and ABC adoption as an optimal CSD. Any misfit between the two is expected to have a negative influence on the outcomes.

Specifically, although using $\mathrm{ABC}$ at low levels of competition, indirect costs and $\mathrm{PC}$ is associated with a low cost of error due to ABC's provision of more accurate product costs that can assist in making informed product-related decisions, using $\mathrm{ABC}$ in such situations is associated with a high cost of measurement (Cooper, 1988b; 1989b; Cooper \& Kaplan, 1991; Stuart, 2013; Drury, 2018). The cost of measurement of using $\mathrm{ABC}$ in such cases will probably exceed $\mathrm{ABC}$ 's benefits in terms of reducing the cost of error, i.e., the benefit of $\mathrm{ABC}$ in relation to the provision of more accurate product costs that can assist in making informed product-related decisions. Therefore, it is uncertain that using $\mathrm{ABC}$ is beneficial at competition, indirect costs and $\mathrm{PC}$ levels that are below those required by $\mathrm{ABC}$.

On the other hand, despite the association with the low cost of measurement, using TCS rather than $\mathrm{ABC}$ at high levels of competition, indirect costs and $\mathrm{PC}$ is associated with a high cost of error due to the provision of inaccurate product costs that leads to the making of inferior product-related decisions (Cooper, 1988b; 1989b; Cooper \& Kaplan, 1991; Stuart, 2013; Drury, 2018). The cost of error when using TCS rather than ABC in such cases will probably outweigh TCS's benefits in terms of reducing the cost of measurement. Accordingly, it is unlikely that TCS is considered beneficial at competition, indirect costs and PC levels higher than those required by TCS. Based on the above discussion, the following three hypotheses will be tested:

H1. From the perspective of the matching form of fit, the level of competition is expected to have a positive influence on ABC adoption as an optimal CSD that generates the highest levels of outcomes. This positive influence includes two elements; namely, a positive association between the level of competition and $A B C$ adoption as an optimal CSD and a negative impact of the misfit between the level of competition and ABC adoption as an optimal CSD on the outcomes.

H2. From the perspective of the matching form of fit, the level of indirect costs is expected to have a positive influence on ABC adoption as an optimal CSD that 
generates the highest levels of outcomes. This positive influence includes two elements; namely, a positive association between the level of indirect costs and $A B C$ adoption as an optimal CSD and a negative impact of the misfit between the level of indirect costs and $A B C$ adoption as an optimal CSD on the outcomes.

H3. From the perspective of the matching form of fit, $P C$ is expected to have a positive influence on ABC adoption as an optimal CSD that generates the highest levels of outcomes. This positive influence includes two elements; namely, a positive association between $P C$ and ABC adoption as an optimal CSD and a negative impact of the misfit between PC and ABC adoption as an optimal CSD on the outcomes.

Regarding the cost of measurement-related factor, the $\mathrm{ABC}$ adoption research suggests that IT quality positively impacts on ABC adoption (Cooper, 1988b; Cooper, 1989b; Al-Omiri \& Drury, 2007; Stuart, 2013; Krumwiede, 1998). High IT quality indicates that a large amount of information concerning various functions - e.g., purchasing and manufacturing - is available in the information system. This, in turn, reduces the cost of measurement of complex costing systems, such as $\mathrm{ABC}$, because the required detailed information about resources, products and production processes and, hence, activities and cost drivers can be obtained at almost no cost (Cooper, 1988b; Cooper, 1989b; Al-Omiri \& Drury, 2007; Stuart, 2013; Krumwiede, 1998; Baxendale \& Jama, 2003; Kaplan \& Cooper, 1998). Another argument suggests that, when the IT quality is high, it is unnecessary to adopt ABC (Krumwiede, 1998). This is due to the satisfaction with the information provided by high-quality information systems, which reduces the desire to invest resources in applying $\mathrm{ABC}$ (ibid). The empirical evidence regarding the effect of IT quality is mixed. Al-Omiri and Drury (2007) found no effect of IT quality on ABC adoption, while Krumwiede (1998) found that IT quality can both encourage and discourage the adoption of ABC. These mixed results can be attributed to one or more of the reasons for the inconsistent results mentioned earlier in this section. Despite these mixed results, the theory supports the positive effect of the IT quality factor on $\mathrm{ABC}$ adoption. This positive relationship between IT quality and $\mathrm{ABC}$ adoption indicates the fit between the two that delivers the highest level of outcomes, reflecting CSD optimality. This suggests a positive relationship between IT quality and ABC adoption as an optimal CSD. Any misfit between the two is anticipated to have a negative influence on the outcomes.

In particular, although using $\mathrm{ABC}$ at low levels of IT quality is linked with a low cost of error because of ABC's provision of more accurate product costs that can assist in making informed product-related decisions, using $\mathrm{ABC}$ in such a situation is associated with a high cost of measurement (Cooper, 1988b; 1989b; Cooper \& Kaplan, 1991; Stuart, 2013; Drury, 2018). The cost of measurement of using ABC in such a case will probably exceed $\mathrm{ABC}$ 's benefits in terms of reducing the cost of 
error, i.e., the benefit of $\mathrm{ABC}$ in relation to the provision of more accurate product costs that can assist in making informed product-related decisions. Thus, it is doubtful that using $\mathrm{ABC}$ is beneficial at IT quality levels lower than those suitable for $\mathrm{ABC}$.

In contrast, notwithstanding the association with the low cost of measurement and the possibility of having high or low costs of error, using TCS rather than ABC at high levels of IT quality can decrease the chance of having more accurate product costs. There is a high possibility that the cost of errors when using TCS rather than $\mathrm{ABC}$ at high levels of IT quality is higher than TCS's benefits regarding reducing the cost of measurement. This, in turn, may reduce the possibility that TCS is considered beneficial at IT quality levels higher than those compatible with TCS. Based on the above, the following hypothesis will be tested:

H4. From the perspective of the matching form of fit, IT quality is expected to have a positive influence on $A B C$ adoption as an optimal CSD that generates the highest levels of outcomes. This positive influence includes two elements; namely, a positive association between IT quality and ABC adoption as an optimal CSD and a negative impact of the misfit between IT quality and ABC adoption as an optimal CSD on the outcomes.

\section{Methodology and methods}

\subsection{Strategy, context, and non-response bias assessment}

In order to achieve the research aim, it is necessary to collect quantitative data from a large number of cases and analyse the data using statistical analysis techniques. Hence, the questionnaire survey strategy was utilised, as it satisfies these needs (Ryan et al., 2002; Collis \& Hussey, 2014). ${ }^{3}$ The questionnaire was designed, constructed, pre-tested and administrated following Dillman et al. (2014)'s guidelines in order to maximise the benefits and minimise the limitations of the questionnaire data collection method. The data for this research were collected from Saudi manufacturing business-units. Saudi Arabia was selected as the research context mainly due to the many significant changes that have been occurring in the country (Ministry of Commerce and Investment (MCI), 2013), including the adoption of the national industrial strategy in 2009 (MCI 2009; Saudi Industrial Development Fund (SIDF), 2009; Burton, 2016), which is now part of the Saudi 2030 Vision (Vision 2030, 2018), and the joining of the World Trading Organisation (WTO) in 2005 (World Trade Organization (WTO), 2020). These changes are anticipated to cause increases in the level of PC and competition, respectively, within certain business-units. These increases, in turn, may result in variations in the levels of CSD and, hence, attract the examination of the impact of 
the level of PC, competition and other related factors on $\mathrm{ABC}$ adoption as an optimal CSD from the perspective of the matching form of fit in Saudi Arabia.

After evaluating the suitability of many databases, including the MCI, SIDF, the Saudi Industrial Property Authority (MODON) and the Royal Commission for Jubail and Yanbu (RCJY) databases, the MODON and RCJY databases were selected because: (1) these two databases do not overlap and, together, cover most of the Saudi industrial cities; (2) the MCI database was being updated; and (3) the SIDF database contained only manufacturing business-unit that obtained support from the fund. Despite being extensive and updated, the MODON and RCJY databases lack important contact details, which made it necessary to make the initial contact with the business-units through visits or phone calls. Making the initial contact in this way necessitated decreasing the sample size of this research to avoid high costs and a lengthy time period. However, it enhanced the validity of the results, since it made it possible to identify accurately the person responsible for assigning the indirect costs, with a solid knowledge about the business-unit which, to the author's knowledge, was not the case in the prior research on $\mathrm{ABC}$ adoption, apart from Hoque (2000). Initially, the questionnaire was sent to 368 contacted business-units, after which multiple phone and e-mail reminders were directed to non-respondents. This process resulted in obtaining 233 responses, representing an initial response rate of $63.3 \%$. Performing checks in relation to missing data, inconsistent questionnaire answers, outliers and normality decreased the number of respondents and response rate to 200 and $54.3 \%$, respectively (Tabachnick \& Fidell, 2007; Hair et al., 2010; Hair et al., 2017). The non-response bias was checked through comparing early respondents $($ total $=120)$ with late ones (total $=80$ ) regarding the examined influential factors on $\mathrm{ABC}$ adoption (Armstrong \& Overton, 1977; Sax et al., 2003; Van der Stede et al., 2005), and no significant differences were found between the two groups.

\subsection{Construct measurement}

The constructs representing the influential factors, $\mathrm{ABC}$ adoption and the outcomes involved in this research were measured based on the prior literature or the researcher's development. Specifically, the level of competition (COMP) was measured using a five-point Likert-scale question adapted from Khandwalla (1972), Drury and Tayles (2000) and Brierley (2007). The level of indirect costs was measured as the percentage of the indirect manufacturing costs to total manufacturing costs (CostStructure-MANUFACTURING) (Brierley, 2007). ${ }^{4}$ Production complexity (PC) was measured using two five-point Likert-scale questions. These questions were developed based on the prior literature (e.g., Estrin et al., 1994; Brierley, 2011; Nguyen \& Brooks, 1997; Swenson, 1998; Cagwin \& Bouwman, 2002; Duh et al., 2009) and the findings of exploratory interviews conducted by the researcher involving eight Saudi manufacturing business-units. The first question concerned the product customisation PC dimension (e.g., 
Bjørnenak, 1997; Brierley, 2011), while the second covered the other five PC dimensions; namely, product complexity (Swenson, 1998), product diversity (Cooper, 1988b), the frequency of introducing new products (Nguyen \& Brooks, 1997), the frequency of making changes to products and manufacturing processes (Cagwin \& Bouwman, 2002) and the production period for products (Duh et al., 2009).

The level of IT quality was measured using a five-point Likert-scale question that attempts to assess the extent to which the business-unit adopts various advanced manufacturing technologies (AMT). These technologies include: (1) product design technologies, e.g., computer-aided design and engineering; (2) process technologies, e.g., flexible manufacturing systems; (3) logistic and planning technologies, e.g., production scheduling systems; and (4) information exchange technologies, e.g., common databases. A question related to AMT was included to measure IT quality due to the association between AMT adoption, IT quality and the cost of measurement (Cooper, 1988b; Kaplan \& Cooper, 1998). Specifically, the adoption of various AMTs increases the amount of available information about the resources, products and production processes and, hence, increases the level of IT quality and decreases the cost of measurement. The AMT question was adapted from Swamidass and Kotha (1998) and Kotha and Swamidass (2000).

$\mathrm{ABC}$ adoption was measured using a multiple-choice question regarding different experiences of $\mathrm{ABC}$ (Brierley, 2011). As shown in Table 1, ABC adoption was operationalised as a dichotomous variable where $\mathrm{ABC}$ adoption includes only $\mathrm{ABC}$ users, while $\mathrm{ABC}$ non-adoption encompasses all other groups of non-users (Ittner et al., 2002; Banker et al., 2008; Maiga et al., 2014).

Table 1. ABC adoption measurements

\begin{tabular}{ll}
\hline ABC adoption definition & ABC non-adoption definition \\
\hline "Currently using ABC" & "Intending to use ABC", "Currently investigating using \\
& ABC", "Intending to investigate using ABC", \\
& "Implemented ABC and subsequently decided to abandon \\
& it", "Investigated using ABC and decided to reject it", \\
& "Investigated using ABC and decided to reject it. \\
& However, the company established a system of activity \\
& analysis (AA) or cost driver analysis (CDA)", "Rejected \\
& ABC, but never considered using it" \\
\hline
\end{tabular}

The optimality of CSD with respect to balancing the cost of error and measurement was indicated using two subjective outcome measures; namely, the respondents' perception of the usefulness and accuracy of cost information (USEFULNESS) and the extent of cost information usage in decision-making (USAGE) (e.g., Pizzini, 2006; Schoute, 2009). These two subjective outcomes were used due to the lack of objective outcome measures that could precisely identify the extent to which the 
CSD is optimal in relation to balancing the cost of error and measurement. USEFULNESS was measured using a five-point Likert-scale question adapted from Drury and Tayles (2000), Pizzini (2006) and Brierley (2008b). USAGE was measured using two five-point Likert-scale questions (Brierley et al., 2006; Schoute, 2009), the first of which concerned the extent of cost information usage in decision-making, while the second the importance of cost information in decisionmaking. USAGE was measured as a weighted-average using the two questions, with importance determining the weight (for an application, see Govindarajan, 1984; Govindarajan \& Gupta, 1985; Chenhall \& Langfield-Smith, 1998; Guenther $\&$ Heinicke, 2018). Table 2 shows the research constructs and their definitions.

Table 2. Research constructs and definitions

\begin{tabular}{ll}
\hline Construct & Definition \\
\hline COMP & The level of competition the business-unit faces. \\
CostStructure- & The level of indirect costs represented by the percentage of \\
MANUFACTURING & indirect manufacturing costs to total manufacturing costs. \\
PC & The level of production complexity. \\
IT quality & The level of information technology quality. \\
ABC adoption & A dichotomous constructs that shows whether the business-unit \\
& adopts ABC or not. \\
USEFULNESS & The respondents' perception of the usefulness and accuracy of \\
& cost information. \\
USAGE & The extent of cost information usage in decision-making. \\
\hline
\end{tabular}

Before assessing the quality of the various latent or multi-indicator constructs, it is important to determine whether the latent construct is reflective or formative. There are many different criteria for differentiating between reflective and formative latent constructs (for example, see Diamantopoulos \& Winklhofer, 2001; Jarvis et al., 2003; Bisbe et al., 2007; Petter et al., 2007; Hair et al., 2010; Hair et al., 2017). ${ }^{5}$ For example, the indicators of the reflective latent constructs should be highly correlated with each other and interchangeable, whereas the opposite is true for those of the formative latent constructs (Hair et al., 2017). Accordingly, removing any indicator affects the nature of the formative latent constructs rather than the reflective ones. After evaluating the constructs based on established criteria to differentiate between reflective and formative latent constructs, COMP and USEFULNESS were classified as reflective latent constructs, whereas PC and IT quality were classified as formative latent constructs. The remaining constructs, namely CostStructure-MANUFACTURING, ABC adoption and USAGE, do not fall into either type of latent construct because they are single-indicator constructs.

The quality of the reflective latent constructs was evaluated using confirmatory factor analysis (Hurley et al., 1997), using partial least squares (PLS) as the estimation method (Tenenhaus \& Hanafi, 2010). The evaluation of the constructs included the internal consistency reliability and convergent and discriminant 
validity (Henseler et al., 2009; Hair et al., 2017). Table 3 provide the results, which indicate that the reflective latent constructs meet the required quality standards.

The quality of the formative latent constructs was evaluated with respect to content validity and the existence of collinearity among the formative indicators (Diamantopoulos \& Winklhofer, 2001; Petter et al., 2007; Hair et al., 2014; Hair et al., 2017). The content validity can be established through either adopting a construct from the prior literature or conducting the following steps: (1) determining the conceptual domain of the formative construct; (2) reviewing the literature extensively to identify a comprehensive list of indicators that covers the construct's conceptual domain; and (3) obtaining expert feedback in relation to the suitability of the chosen indicators (Diamantopoulos \& Winklhofer, 2001; Petter et al., 2007; Hair et al., 2017). The content validity of IT quality was established through adapting a construct from the prior literature (Swamidass \& Kotha, 1998; Kotha \& Swamidass, 2000), while that of PC was established using the abovementioned steps. First, the conceptual domain of PC was determined as any production-related cause for increasing the complexity of the production environment and product cost distortion if TCS rather than ABC was used. Second, the literature review identified 11 possible PC dimensions which, after conducting exploratory interviews with production and cost accounting staff in eight Saudi manufacturing business-units, were reduced to six PC dimensions. Lastly, the indicators of the identified PC dimensions were selected. The second criterion for evaluating the quality of the formative latent constructs, i.e., the existence of collinearity issues, was met, since the variance inflation factor (VIF) of all of the formative indicators was below the threshold values of five (Hair et al., 2011; Hair et al., 2017). For the PC indicators, the VIF values ranged from 1.23 to 2.32, while those for IT quality ranged from 1.50 to 2.39 . The remaining constructs, namely CostStructure-MANUFACTURING, ABC adoption and USAGE, are singleindicator constructs, which means that they have a relationship of 1 with their single indicator and, hence, the constructs and indicators have identical values (Hair et al., 2017).

\section{Results}

\subsection{Descriptive analysis results}

In relation to $\mathrm{ABC}$ adoption, Table 4 displays the numbers and percentages of respondents for each of the various experiences of $\mathrm{ABC}$. The results show that $\mathrm{ABC}$ is used by $19(9.5 \%)$ business-units. In addition, the results indicate that $\mathrm{ABC}$ 
Table 3. The internal consistency reliability and convergent and discriminant validity of the reflective constructs

\begin{tabular}{|c|c|c|c|c|}
\hline & \multicolumn{2}{|c|}{$\begin{array}{l}\text { Internal consistency } \\
\text { reliability (suggested value } \\
\text { between } 0.70 \text { and } 0.95 \text { ) }\end{array}$} & \multirow{2}{*}{$\begin{array}{l}\text { Convergent } \\
\text { validity } \\
\text { (suggested value } \\
\text { of } 0.50 \text { or higher) } \\
\begin{array}{l}\text { Average variance } \\
\text { extracted (AVE) }\end{array}\end{array}$} & \multirow{2}{*}{$\begin{array}{l}\begin{array}{l}\text { Discriminant validity } \\
\text { (suggested values } \mathbf{0 . 8 5}\end{array} \\
\text { and lower) }\end{array}$} \\
\hline Construct & $\begin{array}{l}\text { Cronbach's } \\
\text { Alpha }\end{array}$ & $\begin{array}{l}\text { Composite } \\
\text { reliability }\end{array}$ & & \\
\hline COMP & 0.75 & 0.86 & 0.67 & \multirow{2}{*}{0.17} \\
\hline USEFULNESS & 0.81 & 0.89 & 0.72 & \\
\hline
\end{tabular}

Note: As indicated in this section, COMP refers to the level of competition and USEFULNESS refers to the respondents' perception of the usefulness and accuracy of cost information.

has the potential to be used by $63(31.5 \%)$ business-units, as $34(17 \%)$ businessunits are intending to use $\mathrm{ABC}, 17(8.5 \%)$ are investigating its use and $12(6 \%)$ are intending to investigate its use. Furthermore, the results suggest that the majority of business-units $(\mathrm{n}=101,50.5 \%)$ have never considered using ABC. Moreover, the results show that $17(8.5 \%)$ business-units are unlikely to use the system, given that one $(0.5 \%)$ business-unit had implemented it and subsequently decided to abandon it, while a further $16(8 \%)$ had investigated its use and decided to reject it, with 11 of these 16 business-units deciding to confine its use to the pre-stages of $\mathrm{ABC}$; namely, the activity analysis (AA) or cost driver analysis (CDA). Lastly, the results show that none $(\mathrm{n}=0,0 \%)$ of the business-units rejected $\mathrm{ABC}$ without investigating its use.

Table 4. Business-units' experience with ABC

\begin{tabular}{lrr}
\hline Experience with ABC & $\begin{array}{c}\text { Number } \\
\text { of cases }\end{array}$ & Percentage \\
\hline Currently using ABC & 19 & 9.5 \\
Intending to use ABC & 34 & 17 \\
Currently investigating using ABC & 17 & 8.5 \\
Intending to investigate using ABC & 12 & 6 \\
Implemented ABC and subsequently decided to abandon it & 1 & 0.5 \\
Investigated using ABC and decided to reject it & 5 & 2.5 \\
Investigated using ABC and decided to reject it. However, & & \\
the company established a system of activity analysis (AA) & & \\
or cost driver analysis (CDA) & 11 & 5.5 \\
Rejected ABC, but never considered using it & 0 & 0 \\
Never considered using ABC & 101 & 50.5 \\
\hline Total & 200 & 100 \\
\hline
\end{tabular}

In relation to the influential factors on $\mathrm{ABC}$ adoption and the outcomes of $\mathrm{ABC}$ adoption, Table 5 provides the descriptive statistics. The results show that the level of COMP (mean $=3.86$, median $=4.00$ ) is high, suggesting that the Saudi market 
faces high levels of competition. However, the results show that the level of each of CostStructure-MANUFACTURING (mean $=23.00 \%$, median $=21.00 \%$ ), PC $($ mean $=2.72$, median $=2.69)$ and IT quality $($ mean $=2.69$, median $=2.75)$ is low, indicating that direct manufacturing costs represent the highest percentage of total manufacturing costs, that the overall Saudi production environment is not that complex and that IT in Saudi manufacturing business-units experiences low levels of quality, respectively. Regarding the outcomes, the results show that the level of each of USEFULNESS $($ mean $=4.09$, median $=4.00)$ and USAGE $($ mean $=3.80$, median $=3.90$ ) is high, indicating a high degree of respondents' perception of the usefulness and accuracy of the implemented costing systems and extensive use of cost information in decision-making, respectively.

Table 5. Descriptive statistics for the influential factors on $\mathrm{ABC}$ adoption and the outcomes of $\mathrm{ABC}$ adoption

\begin{tabular}{|c|c|c|c|c|c|c|}
\hline Construct & $\begin{array}{l}\text { Number } \\
\text { of cases }\end{array}$ & Mean & Median & $\begin{array}{l}\text { Standard } \\
\text { Deviation }\end{array}$ & Minimum & Maximum \\
\hline COMP & 200 & 3.86 & 4.00 & 0.68 & 1 & 5 \\
\hline $\begin{array}{l}\text { CostStructure- } \\
\text { MANUFACTURING }\end{array}$ & 200 & 23.00 & 21.00 & 0.14 & 0 & 0.88 \\
\hline $\mathrm{PC}$ & 200 & 2.72 & 2.69 & 0.70 & 1.15 & 5 \\
\hline IT quality & 200 & 2.69 & 2.75 & 1.15 & 1 & 5 \\
\hline USEFULNESS & 200 & 4.09 & 4.00 & 0.70 & 1 & 5 \\
\hline USAGE & 200 & 3.80 & 3.90 & 0.76 & 1.5 & 5 \\
\hline
\end{tabular}

Note: As indicated in Section 4.2, COMP refers to the level of competition, CostStructureMANUFACTURING refers to the level of indirect costs, PC refers to the level of production complexity, IT quality refers to the level of information technology quality, USEFULNESS refers to the respondents' perception of the usefulness and accuracy of cost information and USAGE refers to the extent of cost information usage in decision-making. The descriptive statistics for CostStructureMANUFACTURING pertain to the original rather than the transformed construct.

Table 6 shows the Pearson correlations of all of the constructs involved in this research. It indicates that none of the contingency factors or outcomes has a significant correlation with $\mathrm{ABC}$ adoption, which provides no initial support for the hypotheses. It also shows that USEFULNESS has a significant positive correlation with USAGE, indicating that both outcomes are indicative of the same concept; namely, the optimality of CSD. 
Table 6. The Pearson correlations of all constructs

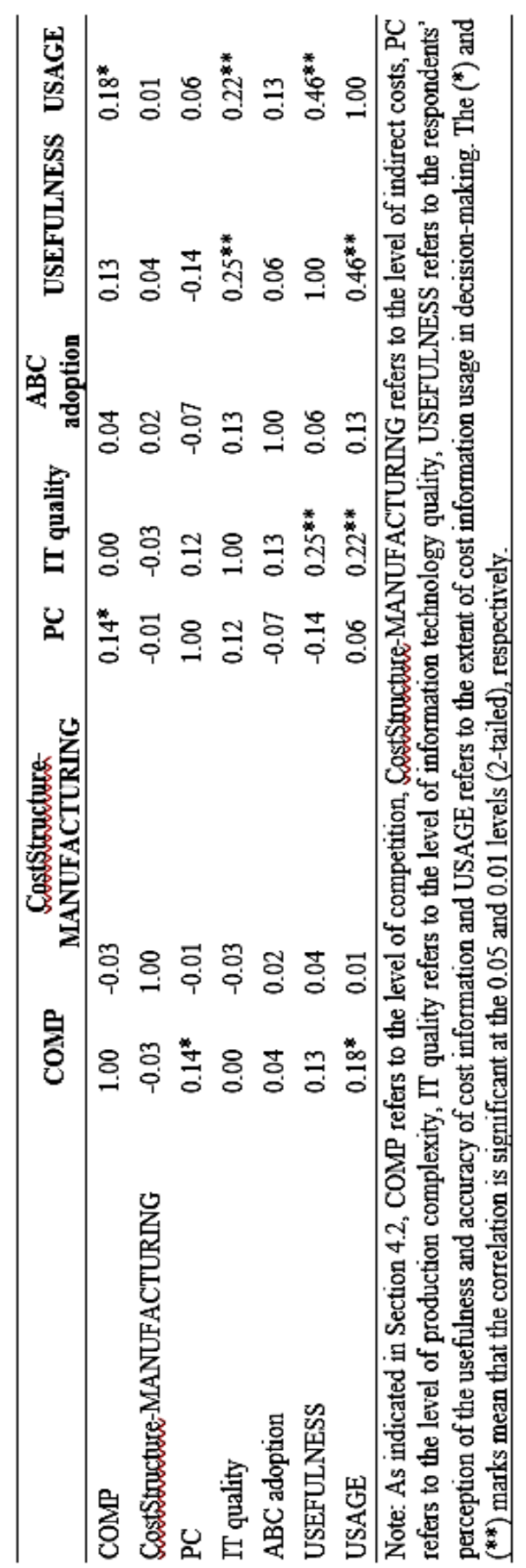

Vol. 19, No. 3 


\subsection{Hypotheses testing results}

The hypotheses were tested using the residual analysis (RA) (Duncan \& Moores, 1989; Dewar \& Werbel, 1979; Ittner \& Larcker, 2001; Ittner et al., 2002). The RA was deemed appropriate to test the matching form of fit's hypotheses, given that the CSD variable, i.e., ABC adoption, is measured using a dichotomous variable (Burkert et al., 2014). The RA was performed using logistic regression analysis that handles dichotomous dependent variables (Pallant, 2013; Field, 2013). The RA entails following two steps to test the matching form of fit's hypotheses. With the assumption that business-units, on average, operate with optimal CSD, the first step is to determine the optimal CSD levels as a function of the influential variables using regression analysis (Ittner et al., 2002; Chen \& Jermias, 2014). The residuals of this regression model, either positive (indicating an over-fit) or negative (indicating an under-fit), represent the distance of each business-unit from the estimated optimal CSD level, i.e., the extent of the misfit (Pizzini, 2006). The first step provides information regarding the first element of the matching form of fit, i.e., the direction of the association between the influential factor and optimal CSD (see Section 1 and hypotheses 1 to 4). The second step of the RA is to regress the outcomes indicating CSD optimality on misfit, represented by two constructs; namely, the absolute values of positive residuals (i.e., over-fit) and the absolute values of negative residuals (i.e., under-fit) (Ittner et al., 2003; Van der Stede et al., 2006; Burkert et al., 2014). The second step furnishes information with respect to the second element of the matching form of fit (i.e., the magnitude and sign of the impact of the misfit on the outcomes) (see Section 1 and hypotheses 1 to 4 ).

\subsubsection{Results of the first step of the RA}

The results of first step of the RA involved estimating four regression models, one for each of the examined influential factors of COMP, CostStructureMANUFACTURING, PC and IT quality. The matching form of fit requires using a separate regression model for each influential factor in order to identify the independent effect of each factor rather than the combined effect of all factors on $\mathrm{ABC}$ adoption as an optimal CSD, i.e., the effect from the standpoint of the system form of fit (see Endnote 2). To illustrate, estimating a separate model for each factor in the first step of the RA results in a misfit value for each, which can be subsequently used in the second step of the RA to identify the independent effect of the factor on $\mathrm{ABC}$ adoption as an optimal CSD. However, if a single regression model, that includes all of the influential factors, is estimated in the first step of the RA, a single misfit value will be obtained and then used in the second step of the RA to identify the combined effect of all of the factors on $\mathrm{ABC}$ adoption as an optimal CSD. 
Table 7 shows the results of the first step, which indicate that each of the four models was insignificant, as indicated by the significance values of the Chi-square goodness of fit test. These results suggest that none of the factors was able to differentiate between $\mathrm{ABC}$ adopters and non-adopters. The insignificance of the models is further illustrated by the low Cox and Snell R square and Nagelkerke R square values, which represent the amount of variation explained in the $\mathrm{ABC}$ adoption dichotomous variable. Furthermore, the insignificance of the models is further supported by the insignificant coefficients of the effects of COMP, CostStructure-MANUFACTURING, PC and IT quality on ABC adoption.

\subsubsection{Results of the second step of the RA}

As discussed in the previous section, none of the first-step regression models pertaining to the influential factors is significant. Hence, this suggests that the optimal CSD could not be identified and so performing the second step to identify the effect of the deviation from the optimal CSD is meaningless. In contrast to expectations, the overall results of the RA indicate that none of the examined factors affects $\mathrm{ABC}$ adoption as an optimal CSD from the perspective of the matching form of fit. Accordingly, hypotheses 1 to 4 are not supported.

\section{Discussion and conclusion}

Due to: (1) the importance of identifying the situations under which $\mathrm{ABC}$ is beneficial and, hence, represents the optimal CSD to make a correct decision about investing in ABC; and (2) the limitations of Ittner et al. (2002) regarding the number of the examined contingency factors and measurement of PC, this paper aimed to examine the key impacts on $\mathrm{ABC}$ adoption as an optimal CSD from the viewpoint of the matching form of fit, utilising a sufficiently comprehensive multidimensional PC measure. Specifically, instead of assessing the effect of a single cost of error-related factor, namely PC, this research examined the influence of three cost of error-related factors - i.e., the level of competition, indirect costs and PC - and the cost of measurement-related factor - i.e., IT quality - on ABC adoption as an optimal CSD from the standpoint of the matching form of fit. Prior $\mathrm{ABC}$ adoption research suggested that, besides $\mathrm{PC}$, the remaining factors also affect ABC adoption as an optimal CSD (Cooper, 1988b; Kaplan \& Cooper, 1998). Therefore, this examination will produce a more refined understanding of the situations under which $\mathrm{ABC}$ adoption is beneficial. In addition, instead of using a limited measure of $\mathrm{PC}$, this research used a sufficiently comprehensive multidimensional PC measure that covers six PC dimensions identified from the prior literature and the findings of exploratory interviews with costing and production staff in eight Saudi manufacturing business-units. This helps to reveal the true effect of $\mathrm{PC}$ on $\mathrm{ABC}$ adoption as an optimal CSD from the perspective of the matching form of fit. 
Table 7. Results of the first step of RA

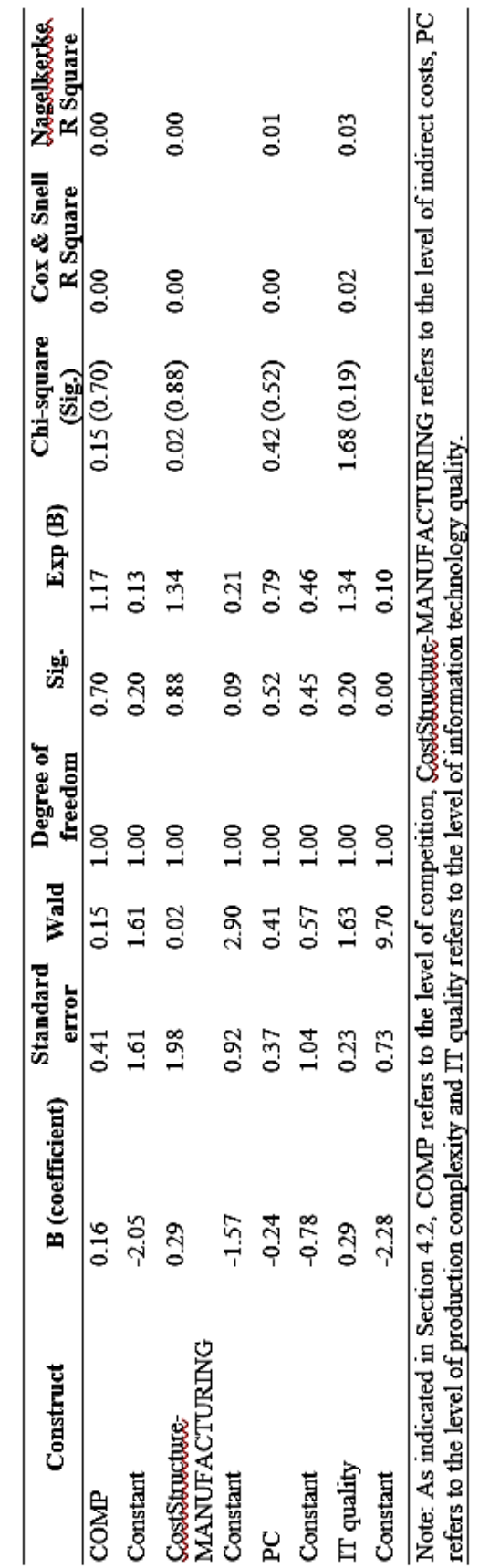


Using questionnaire data collected from Saudi manufacturing business-units, residual analysis (RA) results showed that none of the examined factors influences $\mathrm{ABC}$ adoption as an optimal CSD from the standpoint of the matching form of fit. As shown in Section 5.2.1, none of the logistic regression models was significant in the first step of the RA, which made it meaningless to proceed with the second step. These results were unexpected, given the solid theory behind the effect of the examined factors on $\mathrm{ABC}$ adoption as an optimal CSD from the perspective of the matching form of fit (Cooper, 1988b; Kaplan \& Cooper, 1998; Stuart, 2013). Nevertheless, they are consistent with other studies that found no effect of the level of competition (e.g., Booth \& Giacobbe, 1998; Chen et al., 2001; Chongruksut \& Brooks, 2005; Cohen et al., 2005; Brierley, 2008a; 2011), indirect costs (e.g., Nguyen \& Brooks, 1997; Clarke et al., 1999; Malmi, 1999; Chen et al., 2001; AlMulhem, 2002; Khalid, 2005; Al-Omiri \& Drury, 2007; Brierley, 2011; Nassar et al., 2009), PC (e.g., Clarke et al., 1999; Chen et al., 2001; Brown et al., 2004; Brierley, 2008a; 2011; Nassar et al., 2009) and IT quality (Al-Omiri \& Drury, 2007) on $\mathrm{ABC}$ adoption in general. ${ }^{6}$

There are many possible reasons for the unexpected findings regarding the impact of the examined factors on $\mathrm{ABC}$ adoption as an optimal CSD from the standpoint of the matching form of fit. Regarding the level of competition, it is possible that the COMP construct is limited, since it may need to be broadened by incorporating more dimensions of competition, such as product quality and variety (Khandwalla, 1972; Brierley, 2011). Another possible reason is that the effect of the level of competition on $\mathrm{ABC}$ adoption may be moderated by the ability of the business-unit to set prices. Specifically, the level of competition might affect $\mathrm{ABC}$ adoption when the business-unit is a price maker more than when it is a price taker. Price makers need more accurate cost information to set the price of their products (Drury \& Tayles, 2006; Al-Omiri \& Drury, 2013). However, price takers do not require as highly accurate costs because they use cost information for profitability analysis reasons to ensure that only profitable products are produced and provide attention-directing information about unprofitable products that need further assessment (ibid). With respect to the level of indirect costs, the CostStructureMANUFACTURING measure might have been limited because it included both the unit- and-facility levels' indirect manufacturing costs, that do not affect $\mathrm{ABC}$ adoption, and batch- and product-level indirect manufacturing costs that do influence ABC adoption (Cooper, 1990; Drury \& Tayles, 2005; Al-Omiri \& Drury, 2007). Regarding PC, it is possible that the low level of task uncertainty in low PC environments, where mass production is applied, encourages the adoption of $\mathrm{ABC}$ more than in high PC environments, where job-shop production is utilised, that feature a high level of task uncertainty (Krumwiede, 1998). This can weaken the positive effect of $\mathrm{PC}$ on $\mathrm{ABC}$ adoption or even turn it into a negative one. Another possible reason for the insignificant effect of $\mathrm{PC}$ is that it is possible that 
employees' resistance to highly complex costing systems, such as ABC, may emerge when the level of PC is high (e.g., Hiromoto, 1988; Merchant \& Shields, 1993). A possible reason for this is that the extent of work in high PC environments is too high, making employees resistant to the additional work demands imposed by ABC's complexity. This may reduce or even eliminate any positive effect of $\mathrm{PC}$ on $\mathrm{ABC}$ adoption. Regarding IT quality, it is possible that the majority of business-units use high quality IT due to the decreased costs of these techniques in recent years (Al-Omiri \& Drury, 2007). In addition, it is possible that the satisfaction with information provided by high-quality information systems makes investing resources in applying ABC less desirable (Krumwiede, 1998).

Besides the possible reasons related to each examined variable, there are other possible general reasons for our unexpected findings. The first possible general reason is the existence of organisational variables that execute a significant moderation role on the impact of the examined variables on $\mathrm{ABC}$ adoption as an optimal CSD from the perspective of the matching form of fit. For example, it is possible that the effect of the examined key variables on $\mathrm{ABC}$ adoption as an optimal CSD is only executed when the level of top management support for the costing system is high rather than low. The second possible general reason is the existence of context-related variables that change or eliminate, i.e., moderate, the effect of the examined key variables on ABC adoption as an optimal CSD from the viewpoint of the matching form of fit (Alawattage et al., 2007; Albu \& Albu, 2012). For example, the national culture of Saudi Arabia, which is characterised by a wide power distance that appreciates hierarchies and a strong uncertainty avoidance that is careful and risk-averse to new ideas (Hofstede, 1984), may delay the adaption process of structure and systems, including the costing system, to the surrounding environment. Another example is the legal form of most businessunits in Saudi Arabia, which is family-owned (Joshi et al., 2011; Hanware, 2016; Schumpeter, 2016). Family-owned business-units are managed by family members who may base the investment decisions regarding the costing system on personal preferences rather than logic. For example, family members may reject investing in $\mathrm{ABC}$, although the surrounding context requires it, because they wish to avoid extra costs that would reduce their short-term profits. In contrast, family members may encourage investment in $\mathrm{ABC}$, even though the surrounding context does not require it, because they wish to show off to other family members in the same business-unit or other business-units in the same holding group.

As with all research, this research suffers from many limitations that should be accounted for in future research. First, the measurements of some of the constructs, such as COMP and CostStructure-MANUFACTURING, are limited and, hence, need to be improved by future research in the ways suggested above. Second, 
although the "Rejected $\mathrm{ABC}$, but never considered using it" $\mathrm{ABC}$ experience is included in the definition of $\mathrm{ABC}$ non-adoption (see Table 1), in this research, the number of respondents belonging to this $\mathrm{ABC}$ experience was 0 (see Section 5.1), meaning that this $\mathrm{ABC}$ experience is not actually represented in the utilised definition of $\mathrm{ABC}$ non-adoption. Thus, the results should be interpreted with caution and future research should attempt to collect sufficient data from respondents representing all of the various experiences of ABC adoption. Third, this research assumed that the subjective outcome measures of USEFULNESS and USAGE are able to reflect the extent to which the CSD balances the cost of measurement and error, i.e., the optimality of CSD. Given the unexpected results, this assumption may be unrealistic and, therefore, future research should attempt to develop objective outcome measures for CSD optimality that can indicate the extent to which the CSD balances the cost of measurement and error. Given the difficulty of developing and applying such objective outcome measures when conducting empirical research, non-financial and financial performance seem to be reasonable outcome measures for CSD optimality. These outcome measures are also supported by the fact that the ultimate objective of having optimal CSD is to contribute positively towards overall business-unit performance. Nevertheless, the effect of known variables on performance should be controlled in order to identify the true effect of the fit between $\mathrm{ABC}$ adoption and its influential factors on the outcomes representing the optimality of $\mathrm{ABC}$. Fourth, this research assumed a direct effect of the examined variables - e.g., PC and IT quality - on ABC adoption as an optimal CSD from the viewpoint of the matching form of fit. As mentioned above, this direct effect can be moderated by different organisational variables, such as top management support and organisational culture (Baird et al., 2004; Fullerton et al., 2013; Zhang et al., 2015), and context-related variables, such as national culture (Brewer, 1998). Accordingly, future research should examine the moderation role of these variables on the relationship between the examined variables - e.g., PC and IT quality - and ABC adoption as an optimal CSD from the standpoint of the matching form of fit. This would best be investigated by adopting the cross-sectional field studies strategy, which involves limited-depth studies of a reasonable number of cases, as it allows the uncovering of new insights about either hypothesised or new relationships (Lillis \& Mundy, 2005). Despite these limitations, this research has contributed to the $\mathrm{ABC}$ adoption research by examining the situations under which $\mathrm{ABC}$ is beneficial and, therefore, represents the optimal CSD through testing the effect of the key cost of error-related and the cost of measurement-related factors on ABC adoption as an optimal CSD from the perspective of the matching form of fit, using a sufficiently comprehensive multidimensional PC measure. 


\section{References}

Al-Mulhem, A. (2002) "Activity-based costing system: an analytical and empirical study in Saudi industrial firms", Accounting Research, vol. 6, no. 2: 87-114

Al-Omiri, M. \& Drury, C. (2007) "A survey of factors influencing the choice of product costing systems in UK organizations", Management Accounting Research, vol. 18, no. 4: 399-424

Al-Omiri, M. \& Drury, C. (2013) "A study of factors influencing the choice of product costing systems in KSA Firms", Paper presented at the 36th Annual Congress of the European Accounting Association, Paris, France, 06-08 May

Alawattage, C., Hopper, T. \& Wickramasinghe, D. (2007) "Introduction to management accounting in less developed countries", Journal of Accounting \& Organizational Change, vol. 3, no. 3: 183-191

Albu, N. \& Albu, C. N. (2012) "Factors associated with the adoption and use of management accounting techniques in developing countries: the case of Romania", Journal of International Financial Management \& Accounting, vol. 23 , no. 3: $245-276$

Armstrong, J. S. \& Overton, T. S. (1977) "Estimating nonresponse bias in mail surveys", Journal of Marketing Research, vol. 14, no. 3: 396-402

Baird, K. M., Harrison, G. L. \& Reeve, R. C. (2004) "Adoption of activity management practices: a note on the extent of adoption and the influence of organizational and cultural factors", Management Accounting Research, vol. 15 , no. $4: 383-399$

Banker, R. D., Bardhan, I. R. \& Chen, T. (2008) "The role of manufacturing practices in mediating the impact of activity-based costing on plant performance", Accounting, Organizations and Society, vol. 33, no. 1: 1-19

Baxendale, S. J. \& Jama, F. (2003) "What ERP can offer ABC", Strategic Finance, vol. 85 , no. 2 : $55-57$

Bisbe, J., Batista-Foguet, J. \& Chenhall, R. (2007) "Defining management accounting constructs: a methodological note on the risks of conceptual misspecification", Accounting, Organizations and Society, vol. 32, no. 7: 789-820

Bjørnenak, T. (1997) "Diffusion and accounting: the case of ABC in Norway", Management Accounting Research, vol. 8, no. 1: 3-17

Booth, P. \& Giacobbe, F. (1998) "Predicting the adoption of activity-based costing in Australian manufacturing firms", Paper presented at the 21st Annual Congress of the European Accounting Association, Antwerp, Belgium, 06-08 April.

Brewer, P. C. (1998) "National culture and activity-based costing systems: a note", Management Accounting Research, vol. 9, no. 2: 241-260 
Brierley, J. A. (2007) "Identifying the factors influencing overhead allocation and assignment procedures: an extension", Academy of Taiwan Business Management Review, vol. 3, no. 3: 142-151

Brierley, J. A. (2008a) "An examination of the factors influencing the level of consideration for activity-based costing", International Journal of Business and Management, vol. 3, no. 8: 58-67

Brierley, J. A. (2008b) "Toward an understanding of the sophistication of product costing systems", Journal of Management Accounting Research, vol. 20, no. Special issue: $61-78$

Brierley, J. A. (2011) "Why the proper definition of the ABC matters: a note", Advances in Management Accounting, vol. 19, 239-263

Brierley, J. A., Cowton, C. J. \& Drury, C. (2001) "Research into product costing practice: a European perspective", European Accounting Review, vol. 10, no. $2: 215-256$

Brierley, J. A., Cowton, C. J. \& Drury, C. (2006) "A note on the importance of product costs in decision-making", Advances in Management Accounting, vol. 15, 249-265

Brown, D. A., Booth, P. \& Giacobbe, F. (2004) "Technological and organizational influences on the adoption of activity- based costing in Australia", Accounting \& Finance, vol. 44, no. 3: 329-356

Burkert, M., Davila, A., Mehta, K. \& Oyon, D. (2014) "Relating alternative forms of contingency fit to the appropriate methods to test them", Management Accounting Research, vol. 25, no. 1: 6-29

Burton, E. (2016) Business and entrepreneurship in Saudi Arabia: opportunities for partnering and investing in emerging businesses, Hoboken, New Jersey: John Wiley \& Sons, Inc.

Cagwin, D. \& Bouwman, M. J. (2002) "The association between activity-based costing and improvement in financial performance", Management Accounting Research, vol. 13, no. 1: 1-39

Charaf, K. \& Bescos, P. (2013) "The role of organizational and cultural factors in the adoption of activity-based costing: the case of Moroccan firms", Journal of Accounting \& Management Information Systems, vol. 12, no. 1: 4-21

Chen, G., Firth, M. \& Park, K. (2001) "The implementation and benefits of activity-based costing: a Hong Kong study", Asian Review of Accounting, vol. 9, no. 2: 23-37

Chen, Y. \& Jermias, J. (2014) "Business strategy, executive compensation and firm performance", Accounting \& Finance, vol. 54, no. 1: 113-134

Chenhall, R. H. (2003) "Management control systems design within its organizational context: findings from contingency-based research and directions for the future", Accounting, Organizations and Society, vol. 28, no. 2-3: $127-168$ 
Chenhall, R. H. (2007) "Theorizing contingencies in management control systems research", In C. S. Chapman, A. G. Hopwood \& M. D. Shields, (Ed.), Handbook of management accounting research. (1st edition), Oxford, UK: Elsevier, pp. 163-205

Chenhall, R. H. \& Chapman, C. S. (2006) "Theorising and testing fit in contingency research on management control systems", In Z. Hoque, (Ed.), Methodological issues in accounting research: theories and methods, London, UK: Spiramus Press Ltd, pp. 35-54

Chenhall, R. H. \& Langfield-Smith, K. (1998) "The relationship between strategic priorities, management techniques and management accounting: an empirical investigation using a systems approach", Accounting, Organizations and Society, vol. 23, no. 3: 243-264

Chongruksut, W. \& Brooks, A. (2005) "The adoption and implementation of activity-based costing in Thailand", Asian Review of Accounting, vol. 13, no. 2: 1-17

Clarke, P. J., Hill, N. T. \& Stevens, K. (1999) "Activity-based costing in Ireland: barriers to, and opportunities for, change"., Critical Perspectives on Accounting, vol. 10, no. 4: 443-468

Cohen, S., Venieris, G. \& Kaimenaki, E. (2005) "ABC: adopters, supporters, deniers and unawares", Managerial Auditing Journal, vol. 20, no. 9: 9811000

Collis, J. \& Hussey, R. (2014) Business research: a practical guide for undergraduate and postgraduate students, (4th edition) Basingstoke, UK: Palgrave Macmillan

Cooper, R. (1988a) "The rise of activity-based costing - part one: what is an activity-based cost system?.", Journal of Cost Management for the Manufacturing Industry, vol. 2, no. Summer: 45-54

Cooper, R. (1988b) "The rise of activity-based costing - part two: when do I need an activity-based cost system?", Journal of Cost Management for the Manufacturing Industry, vol. 2, no. Fall: 41-48

Cooper, R. (1989a) "The rise of activity-based costing - part three: how many cost drivers do you need, and how do you select them?", Journal of Cost Management for the Manufacturing Industry, vol. 3, no. Winter: 34-46

Cooper, R. (1989b) "You need a new cost system when", Harvard Business Review, no. January-February: 77-82

Cooper, R. (1990) "Cost classification in unit-based and activity-based manufacturing cost systems", Journal of Cost Management for the Manufacturing Industry, vol. 4, no. Fall: 4-14

Cooper, R. \& Kaplan, R. S. (1991) The design of cost management systems: text, cases, and readings, Englewood Cliffs, New Jersey: Prentice-Hall, Inc.

Dewar, R. \& Werbel, J. (1979) "Universalistic and contingency predictions of employee satisfaction and conflict", Administrative Science Quarterly, vol. 24, no. 3: $426-448$ 
Diamantopoulos, A. \& Winklhofer, H. M. (2001) "Index construction with formative indicators: an alternative to scale development", Journal of Marketing Research, vol. 38, no. 2: 269-277

Dillman, D. A., Smyth, J. D. \& Christian, L. M. (2014) Internet, phone, mail, and mixed-mode surveys: the tailored design method, 4th edition, Hoboken, New Jersey: John Wiley \& Sons, Inc.

Donaldson, L. (2001) The contingency theory of organizations, Thousand Oaks, California: SAGE Publications, Inc.

Drury, C. (2018) Management and cost accounting, 10th edition, Andover, UK: Cengage Learning EMEA

Drury, C. \& Tayles, M. (2000) Cost system design and profitability analysis in UK companies. London, UK: The Chartered Institute of Management Accountants

Drury, C. \& Tayles, M. (2005) "Explicating the design of overhead absorption procedures in UK organizations", The British Accounting Review, vol. 37, no. 1: 47-84

Drury, C. \& Tayles, M. (2006) "Profitability analysis in UK organizations: an exploratory study", The British Accounting Review, vol. 38, no. 4: 405-425

Duh, R., Lin, T. W., Wang, W. \& Huang, C. (2009) "The design and implementation of activity-based costing: a case study of a Taiwanese textile company", International Journal of Accounting and Information Management, vol. 17, no. 1: 27-52

Duncan, K. \& Moores, K. (1989) "Residual analysis: a better methodology for contingency studies in management accounting", Journal of Management Accounting Research, vol. 1, no. Fall: 89-103

Elhamma, A. (2012) "The relationship between firm size, activity based costing and performance: an application on Moroccan enterprises", Journal of Accounting, Business \& Management, vol. 19, no. 1: 90-102

Elhamma, A. \& Zhang, Y. F. (2013) "The relationship between activity based costing, business strategy and performance in Moroccan enterprises", Accounting and Management Information Systems, vol. 12, no. 1: 22-38

Estrin, T., Kantor, J. \& Albers, D. (1994) "Is ABC suitable for your company?", Management Accounting, no. April: 40-45

Field, A. (2013) Discovering statistics using IBM SPSS statistics, 4th edition, London, UK: SAGE Publications Ltd.

Frey, K. \& Gordon, L. A. (1999) "ABC, strategy and business unit performance", International Journal of Applied Quality Management, vol. 2, no. 1: 1-23

Fullerton, R. R., Kennedy, F. A. \& Widener, S. K. (2013) "Management accounting and control practices in a lean manufacturing environment", Accounting, Organizations and Society, vol. 38, no. 1: 50-71

Gerdin, J. (2005a) "The impact of departmental interdependencies and management accounting system use on subunit performance", European Accounting Review, vol. 14, no. 2: 297-327 
Gerdin, J. (2005b) "The impact of departmental interdependencies and management accounting system use on subunit performance: a second look", European Accounting Review, vol. 14, no. 2: 335-340

Gerdin, J. \& Greve, J. (2004) "Forms of contingency fit in management accounting research - a critical review", Accounting, Organizations and Society, vol. 29, no. 3: 303-326

Gerdin, J. \& Greve, J. (2008) "The appropriateness of statistical methods for testing contingency hypotheses in management accounting research", Accounting, Organizations and Society, vol. 33, no. 7-8: 995-1009

Gosselin, M. (1997) "The effect of strategy and organizational structure on the adoption and implementation of activity-based costing", Accounting, Organizations and Society, vol. 22, no. 2: 105-122

Govindarajan, V. (1984) "Appropriateness of accounting data in performance evaluation: an empirical examination of environmental uncertainty as an intervening variable", Accounting, Organizations and Society, vol. 9, no. 2: $125-135$

Govindarajan, V. \& Gupta, A. K. (1985) "Linking control systems to business unit strategy: impact on performance", Accounting, Organizations and Society, vol. 10, no. 1: 51-66

Guenther, T. W. \& Heinicke, A. (2018) "Relationships among types of use, levels of sophistication, and organizational outcomes of performance measurement systems: the crucial role of design choices", Management Accounting Research, vol. 42, 1-25

Hair, J. F., Black, W. C., Babin, B. J. \& Anderson, R. E. (2010) Multivariate data analysis: a global perspective, Global edition 7th edition, Upper Saddle River, New Jersey: Pearson Prentice Hall

Hair, J. F., Hult, G. T. M., Ringle, C. M. \& Sarstedt, M. (2017) A primer on partial least squares structural equation modeling (PLS-SEM), 2nd edition, Thousand Oaks, California: SAGE Publications, Inc.

Hair, J. F., Ringle, C. M. \& Sarstedt, M. (2011) "PLS-SEM: indeed a silver bullet", Journal of Marketing Theory and Practice, vol. 19, no. 2: 139-152

Hair, J. F., Sarstedt, M., Hopkins, L. \& Kuppelwieser, V. G. (2014) "Partial least squares structural equation modeling (PLS-SEM) an emerging tool in business research", European Business Review, vol. 26, no. 2: 106-121

Hanware, K. (2016) "Family-owned businesses flourishing in Kingdom", available on-line at http://www.arabnews.com/economy/news/909011\#, Retrieved July 26, 2020

Hartmann, F. G. H. (2005) "The impact of departmental interdependencies and management accounting system use on subunit performance: a comment", European Accounting Review, vol. 14, no. 2: 329-334

Henseler, J., Ringle, C. M. \& Sinkovics, R. R. (2009) "The use of partial least squares path modeling in international marketing", Advances in International Marketing, vol. 20, 277-319 
Hiromoto, T. (1988) "Another hidden edge-Japanese management accounting". Harvard Business Review, no. July-August: 22-25

Hofstede, G. (1984) "Cultural dimensions in management and planning", Asia Pacific Journal of Management, vol. 1, no. 2: 81-99

Hoque, Z. (2000) "Just-In-Time production, automation, cost allocation practices and importance of cost information: an empirical investigation in New Zealand-based manufacturing organizations", The British Accounting Review, vol. 32, no. 2: 133-159

Hurley, A. E., Scandura, T. A., Schriesheim, C. A., Brannick, M. T., Seers, A., Vandenberg, R. J. \& Williams, L. J. (1997) "Exploratory and confirmatory factor analysis: guidelines, issues, and alternatives", Journal of Organizational Behavior, vol. 18, no. 6: 667-683

Ittner, C. D., Lanen, W. N. \& Larcker, D. F. (2002) "The association between activity based costing and manufacturing performance", Journal of Accounting Research, vol. 40, no. 3: 711-726

Ittner, C. D. \& Larcker, D. F. (2001) "Assessing empirical research in managerial accounting: a value-based management perspective", Journal of Accounting and Economics, vol. 32, no. 1: 349-410

Ittner, C. D., Larcker, D. F. \& Randall, T. (2003) "Performance implications of strategic performance measurement in financial services firms", Accounting, Organizations and Society, vol. 28, no. 7: 715-741

Jarvis, C. B., MacKenzie, S. B. \& Podsakoff, P. M. (2003) "A critical review of construct indicators and measurement model misspecification in marketing and consumer research", Journal of Consumer Research, vol. 30, no. 2: 199-218

Joshi, P. L., Bremser, W. G., Deshmukh, A. \& Kumar, R. (2011) "Diffusion of management accounting practices in Gulf Cooperation Council countries", Accounting Perspectives, vol. 10, no. 1: 23-53

Jusoh, R. \& Miryazdi, S. M. (2016) "The influence of technological and environmental factors on the diffusion of activity-based costing in Iran", TÉKHNE - Review of Applied Management Studies, vol. 13, no. 2: 95-109

Kallunki, J.-P. \& Silvola, H. (2008) "The effect of organizational life cycle stage on the use of activity-based costing", Management Accounting Research, vol. 19, no. 1: 62-79

Kaplan, R. S. \& Cooper, R. (1998) Cost \& effect: using integrated cost systems to drive profitability and performance, Boston, Massachusetts: Harvard Business School Press

Khalid, A. (2005) "Activity-based costing in Saudi Arabia's largest 100 firms in 2003", Journal of American Academy of Business, Cambridge, vol. 6, no. 2: $285-292$

Khandwalla, P. N. (1972) "The effect of different types of competition on the use of management controls", Journal of Accounting Research, vol. 10, no. 2: $275-285$ 
Klaas, P. \& Donaldson, L. (2009) "Underfits versus overfits in the contingency theory of organizational design: asymmetric effects of misfits on performance", In A. Bøllingtoft, D. D. Håkonsson, J. F. Nielsen, C. C. Snow \& J. Ulhøi, (Ed.), New approaches to organization design: theory and practice of adaptive enterprises, New York, New York: Springer Science, Business Media, LLC, pp. 147-168

Kotha, S. \& Swamidass, P. M. (2000) "Strategy, advanced manufacturing technology and performance: empirical evidence from US manufacturing firms", Journal of Operations Management, vol. 18, no. 3: 257-277

Krumwiede, K. R. (1998) "The implementation stages of activity-based costing and the impact of contextual and organizational factors", Journal of Management Accounting Research, vol. 10, 239-277

Krumwiede, K. R. \& Charles, S. L. (2014) "The use of activity-based costing with competitive strategies: impact on firm performance", Advances in Management Accounting, vol. 23, 113-148

Lillis, A. M. \& Mundy, J. (2005) "Cross-sectional field studies in management accounting research-closing the gaps between surveys and case studies", Journal of Management Accounting Research, vol. 17, no. 1: 119-141

Maiga, A. S., Nilsson, A. \& Jacobs, F. A. (2014) "Assessing the interaction effect of cost control systems and information technology integration on manufacturing plant financial performance", The British Accounting Review, vol. 46, no. 1: 77-90

Malmi, T. (1999) "Activity-based costing diffusion across organizations: an exploratory empirical analysis of Finnish firms", Accounting, Organizations and Society, vol. 24, no. 8: 649-672

Meilich, O. (2006) "Bivariate models of fit in contingency theory: critique and a polynomial regression alternative", Organizational Research Methods, vol. 9, no. 2: 161-193

Merchant, K. A. \& Shields, M. D. (1993) "When and why to measure costs less accurately to improve decision making", Accounting Horizons, vol. 7, no. 2: 76-81

Ministry of Commerce and Investment (MCI) (2009) The national industrial strategy until 2020 and implementation mechanisms. Saudi Arabia: MCI.

Ministry of Commerce and Investment (MCI) (2013) Industrial developments in Saudi Arabia. Saudi Arabia: MCI.

Nassar, M., Morris, D., Thomas, A. \& Sangster, A. (2009) "An empirical study of activity-based costing (ABC) systems within the Jordanian industrial sector: critical success factors and barriers to ABC implementation", Research in Accounting in Emerging Economies, vol. 9, 229-263

Nguyen, H. V. \& Brooks, A. (1997) "An empirical investigation of adoption issues relating to activity-based costing", Asian Review of Accounting, vol. 5, no. $1: 1-18$

Pallant, J. (2013) SPSS survival manual, 5th edition, Maidenhead, UK: Open University Press, McGraw-Hill Education. 
Petter, S., Straub, D. \& Rai, A. (2007) "Specifying formative constructs in information systems research", MIS Quarterly, vol. 31, no. 4: 623-656

Pizzini, M. J. (2006) "The relation between cost-system design, managers' evaluations of the relevance and usefulness of cost data, and financial performance: an empirical study of US hospitals", Accounting, Organizations and Society, vol. 31, no. 2: 179-210

Pokorná, J. (2015) "The expansion of activity-based costing/management in the Czech Republic", Central European Journal of Management, vol. 2, no. 1-2: $35-49$

Ryan, B., Scapens, R. W. \& Theobald, M. (2002) Research methods and methodology in accounting and finance, 2nd edition, London, UK: Thomson

Saudi Industrial Development Fund (SIDF) (2009) Annual report for the fiscal year 1430/1431H (2009G) Saudi Arabia: SIDF.

Sax, L. J., Gilmartin, S. K. \& Bryant, A. N. (2003) "Assessing response rates and nonresponse bias in web and paper surveys", Research in Higher Education, vol. 44, no. 4: 409-432

Schoonhoven, C. B. (1981) "Problems with contingency theory: testing assumptions hidden within the language of contingency theory", Administrative Science Quarterly, vol. 26, no. 3: 349-377

Schoute, M. (2009) "The relationship between cost system complexity, purposes of use, and cost system effectiveness", The British Accounting Review, vol. 41, no. 4: 208-226

Schoute, M. (2011) "The relationship between product diversity, usage of advanced manufacturing technologies and activity-based costing adoption", The British Accounting Review, vol. 43, no. 2: 120-134

Schumpeter. (2016) "Succession failure", available on-line at http://www.economist.com/news/business/21690027-family-businessesarabian-gulf-need-address-problem-succession (Retrieved July 26, 2020)

Stuart, N. V. (2013) "Assessing the costs and benefits of investing in cost system accuracy", Journal of Corporate Accounting \& Finance, vol. 25, no. 1: 59-68

Swamidass, P. M. \& Kotha, S. (1998) "Explaining manufacturing technology use, firm size and performance using a multidimensional view of technology", Journal of Operations Management, vol. 17, no. 1: 23-37

Swenson, D. W. (1998) "Managing costs through complexity reduction at Carrier corporation", Management Accounting, no. April: 20-28

Tabachnick, B. G. \& Fidell, L. S. (2007) Using multivariate statistics, 5th edition, Boston, Massachusetts: Pearson Education, Inc.

Tenenhaus, M. \& Hanafi, M. (2010) "A bridge between PLS path modeling and multi-block data analysis", In V. E. Vinzi, W. W. Chin, J. Henseler \& H. Wang, (Ed.) Handbook of partial least squares: concepts, methods, and applications, Berlin, Germany: Springer Science, Business Media, LLC, pp. $99-123$ 
Van der Stede, W. A., Chow, C. W. \& Lin, T. W. (2006) "Strategy, choice of performance measures, and performance", Behavioral Research in Accounting, vol. 18, no. 1: 185-205

Van der Stede, W. A., Young, S. M. \& Chen, C. X. (2005) "Assessing the quality of evidence in empirical management accounting research: the case of survey studies", Accounting, Organizations and Society, vol. 30, no. 7: 655-684

Vision 2030. (2018) National Industrial Development \& Logistics Program (Delivery Plan 2018-2020) Saudi Arabia: Vision 2030.

World Trade Organization (WTO) (2020) "Member information: Kingdom of Saudi Arabia", available on-line at http://www.wto.org/english/thewto_e /countries_e/saudi_arabia_e.htm (Retrieved July 31, 2020)

Zhang, Y. F., Hoque, Z. \& Isa, C. R. (2015) "The effects of organizational culture and structure on the success of activity-based costing implementation", Advances in Management Accounting, vol. 25, 229-257.

\section{Appendix: Relevant extracts from the questionnaire}

\section{Competition (COMP)}

What is the level of intensity or weakness of each of the following types of competition? (Please circle the appropriate number.)

\begin{tabular}{|lccccc} 
& $\begin{array}{c}\text { Very } \\
\text { weak }\end{array}$ & Weak & Moderate & Intense & $\begin{array}{c}\text { Very } \\
\text { intense }\end{array}$ \\
\hline a. $\quad \begin{array}{l}\text { The current level of competition } \\
\text { for the major products of your } \\
\text { business unit. }\end{array}$ & 1 & 2 & 3 & 4 & 5 \\
\hline $\begin{array}{l}\text { The level of price competition for } \\
\text { your business unit's major } \\
\text { products. }\end{array}$ & 1 & 2 & 3 & 4 & 5 \\
\hline $\begin{array}{l}\text { The level of competition for } \\
\text { purchasing raw materials for your } \\
\text { business unit's major products. }\end{array}$ & 1 & 2 & 3 & 4 & 5 \\
\hline
\end{tabular}

\section{The level of indirect costs (CostStructure MANUFACTURING)}

What is the percentage of each of the following costs in your business unit's total costs? (Please insert the appropriate percentage.)

Direct manufacturing costs.

Indirect/overhead manufacturing costs.

Non-manufacturing costs.

Total costs.

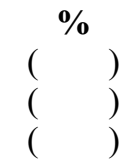




\section{Production complexity (PC)}

Which of the following best describes the percentage of the customised and standardised products produced by your business unit? (Please circle the appropriate number.)

1. At least $95 \%$ of products are standardised.

2. Approximately $75 \%$ of products are standardised, and $25 \%$ of products are customised.

3. Approximately $50 \%$ of products are standardised and $50 \%$ of products are customised.

4. Approximately $75 \%$ of products are customised, and $25 \%$ of products are standardised.

5. At least $95 \%$ of products are customised.

To what extent do each of the following statements apply or do not apply to your business unit's products and production environment? (Please circle the appropriate number.)

\begin{tabular}{|c|c|c|c|}
\hline $\begin{array}{l}\text { Not } \\
\text { at all }\end{array}$ & $\begin{array}{l}\text { To a } \\
\text { little } \\
\text { extent }\end{array}$ & $\begin{array}{l}\text { To } \\
\text { some } \\
\text { extent }\end{array}$ & $\begin{array}{l}\text { To a } \\
\text { considerable } \\
\text { extent }\end{array}$ \\
\hline
\end{tabular}

\begin{tabular}{llllll} 
a. $\begin{array}{l}\text { Most products are complex to } \\
\text { produce because they contain large } \\
\text { number of components. }\end{array}$ & 2 & 3 & 4 & 5 \\
\hline $\begin{array}{l}\text { bost products are complex to } \\
\text { produce because they need to pass } \\
\text { through large number of production } \\
\text { stages/departments. }\end{array}$ & 1 & 2 & 3 & 4 & 5 \\
c. $\begin{array}{l}\text { A large number of different } \\
\text { products are produced. }\end{array}$ & 1 & 2 & 3 & 4 & 5 \\
d. $\begin{array}{l}\text { Most products are produced in } \\
\text { significantly different sizes. }\end{array}$ & 1 & 2 & 3 & 4 & 5 \\
e. $\begin{array}{l}\text { There are major differences in } \\
\text { product volumes or batch sizes. }\end{array}$ & 1 & 2 & 3 & 4 & 5 \\
f. $\begin{array}{l}\text { The manufacturing process is not } \\
\text { standardised because changes to the } \\
\text { production process need to be made } \\
\text { if some factors (e.g., the type of } \\
\text { material or machine) have been } \\
\text { changed. }\end{array}$ & 1 & 2 & 3 & 4 & 5 \\
\hline The production processes for most \\
$\begin{array}{l}\text { products take a long time. } \\
\text { Most products require different } \\
\text { processes to design, manufacture } \\
\text { and distribute them. }\end{array}$
\end{tabular}


There are frequent new product introductions.

\begin{tabular}{l|llll} 
Not & To a & To & To a & To a \\
at all little & $\begin{array}{l}\text { some } \\
\text { extent }\end{array}$ & $\begin{array}{l}\text { considerable } \\
\text { extent }\end{array}$ & $\begin{array}{l}\text { very } \\
\text { exent } \\
\text { extent }\end{array}$ \\
\hline
\end{tabular}

k. There are frequent changes in products and production processes.

1. Each product line requires different levels of support department costs (e.g., engineering, purchasing and

$\begin{array}{lllll}1 & 2 & 3 & 4 & 5 \\ 1 & 2 & 3 & 4 & 5 \\ 1 & 2 & 3 & 4 & 5\end{array}$
(e.g., engineering,
marketing costs)

\section{The level of information technology quality (IT quality)}

To what extent, if at all, does your business unit use the following types of advanced manufacturing technologies? (Please circle the appropriate number.)

\begin{tabular}{|c|c|c|c|c|c|c|}
\hline & & $\begin{array}{l}\text { Not at } \\
\text { all }\end{array}$ & $\begin{array}{l}\text { To a } \\
\text { little } \\
\text { extent }\end{array}$ & $\begin{array}{l}\text { To } \\
\text { some } \\
\text { extent }\end{array}$ & $\begin{array}{l}\text { To a } \\
\text { considerable } \\
\text { extent }\end{array}$ & $\begin{array}{l}\text { To a } \\
\text { very } \\
\text { great } \\
\text { extent }\end{array}$ \\
\hline 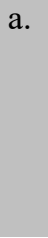 & $\begin{array}{l}\text { Product design technologies: } \\
\text { These technologies are used in } \\
\text { designing the product (e.g., } \\
\text { Computer Aided Design (CAD) } \\
\text { and Computer Aided } \\
\text { Engineering (CAE)). }\end{array}$ & 1 & 2 & 3 & 4 & 5 \\
\hline b. & $\begin{array}{l}\text { Process technologies: These } \\
\text { technologies are used on the } \\
\text { shop floor, and provide } \\
\text { information related to the } \\
\text { manufacturing process (e.g., } \\
\text { Computer Aided } \\
\text { Manufacturing (CAM) and } \\
\text { Flexible Manufacturing } \\
\text { Systems (FMS)). }\end{array}$ & 1 & 2 & 3 & 4 & 5 \\
\hline c. & $\begin{array}{l}\text { Logistic/planning technologies: } \\
\text { These technologies are used to } \\
\text { control the material flow from } \\
\text { the stage of obtaining raw } \\
\text { material to the stage of } \\
\text { delivering finished products } \\
\text { (e.g., Material Requirement } \\
\text { Planning systems (MRP). }\end{array}$ & 1 & 2 & 3 & 4 & 5 \\
\hline d. & $\begin{array}{l}\text { Information exchange } \\
\text { technologies: These } \\
\text { technologies are used to } \\
\text { facilitate storing and } \\
\text { exchanging information among }\end{array}$ & 1 & 2 & 3 & 4 & 5 \\
\hline
\end{tabular}


, product and logistic

technologies (e.g., Electronic

Data Interchange (EDI)).

\begin{tabular}{|c|c|c|c|}
\hline $\begin{array}{l}\text { Not at } \\
\text { all }\end{array}$ & $\begin{array}{l}\text { To a } \\
\text { little } \\
\text { extent }\end{array}$ & $\begin{array}{l}\text { To } \\
\text { some } \\
\text { extent }\end{array}$ & $\begin{array}{l}\text { To a } \\
\text { considerable } \\
\text { extent }\end{array}$ \\
\hline
\end{tabular}

\section{ABC adoption}

Which of the following best describes your business unit's experience with activitybased costing (ABC)? (Please circle the appropriate number.)

1. Currently using ABC.

2. Intending to use ABC.

3. Currently investigating using $\mathrm{ABC}$.

4. Intending to investigate using $\mathrm{ABC}$.

5. Implemented $\mathrm{ABC}$ and subsequently decided to abandon it.

6. Investigated using $\mathrm{ABC}$ and decided to reject it.

7. Investigated using $\mathrm{ABC}$ and decided to reject it. However, the company established a system of activity analysis or cost driver analysis.

8. Rejected $\mathrm{ABC}$, but never considered using it.

9. Never considered using ABC.

\section{The respondents' perception of the usefulness and accuracy of cost information}

\section{(USEFULNESS)}

To what extent do you agree or disagree with the following statements relating to your perception of the usefulness and accuracy of your costing system in calculating product costs for the purpose of decision making? (Please circle the appropriate number.)

\begin{tabular}{|c|c|c|c|c|c|c|}
\hline & & $\begin{array}{l}\text { Strongly } \\
\text { disagree }\end{array}$ & Disagree & Neutral & Agree & $\begin{array}{l}\text { Strongly } \\
\text { agree }\end{array}$ \\
\hline a. & $\begin{array}{l}\text { The business unit's costing } \\
\text { system provides product } \\
\text { cost information that is } \\
\text { useful when making } \\
\text { different decisions. }\end{array}$ & 1 & 2 & 3 & 4 & 5 \\
\hline b. & $\begin{array}{l}\text { I rely on product cost } \\
\text { information generated by } \\
\text { the business unit's costing } \\
\text { system to make different } \\
\text { decisions. }\end{array}$ & 1 & 2 & 3 & 4 & 5 \\
\hline c. & $\begin{array}{l}\text { I am satisfied with the } \\
\text { accuracy of the business } \\
\text { unit's costing system at } \\
\text { assigning indirect costs to } \\
\text { products for the purpose of } \\
\text { decision making. }\end{array}$ & 1 & 2 & 3 & 4 & 5 \\
\hline
\end{tabular}


The influences on Activity-Based Costing adoption as an optimal costing system design: Evidence from Saudi Arabia

The extent of cost information usage in decision-making (USAGE)

To what extent, if at all, does your business unit use product cost information in the following decisions? (Please circle the appropriate number.)

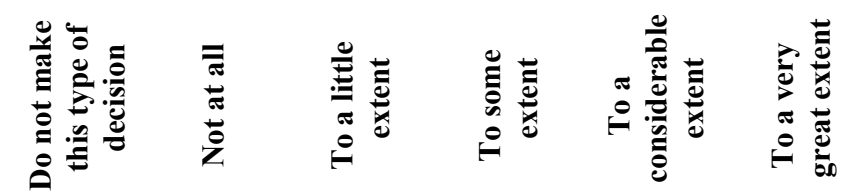

\begin{tabular}{|c|c|c|c|c|c|c|c|}
\hline a. & $\begin{array}{l}\text { Product pricing } \\
\text { decisions. }\end{array}$ & 0 & 1 & 2 & 3 & 4 & 5 \\
\hline b. & $\begin{array}{l}\text { Make or buy } \\
\text { decisions. }\end{array}$ & 0 & 1 & 2 & 3 & 4 & 5 \\
\hline c. & $\begin{array}{l}\text { Cost reduction } \\
\text { decisions. }\end{array}$ & 0 & 1 & 2 & 3 & 4 & 5 \\
\hline d. & $\begin{array}{l}\text { Product mix } \\
\text { decisions. }\end{array}$ & 0 & 1 & 2 & 3 & 4 & 5 \\
\hline e. & $\begin{array}{l}\text { Product output level } \\
\text { decisions. }\end{array}$ & 0 & 1 & 2 & 3 & 4 & 5 \\
\hline f. & $\begin{array}{l}\text { Product design } \\
\text { decisions. }\end{array}$ & 0 & 1 & 2 & 3 & 4 & 5 \\
\hline g. & $\begin{array}{l}\text { Evaluating new } \\
\text { production process } \\
\text { decisions. }\end{array}$ & 0 & 1 & 2 & 3 & 4 & 5 \\
\hline h. & $\begin{array}{l}\text { Product introduction } \\
\text { decisions. }\end{array}$ & 0 & 1 & 2 & 3 & 4 & 5 \\
\hline i. & $\begin{array}{l}\text { Product } \\
\text { discontinuation } \\
\text { decisions. }\end{array}$ & 0 & 1 & 2 & 3 & 4 & 5 \\
\hline
\end{tabular}

For your business unit, how important or unimportant is product cost information for each of the following decisions? (Please circle the appropriate number.)

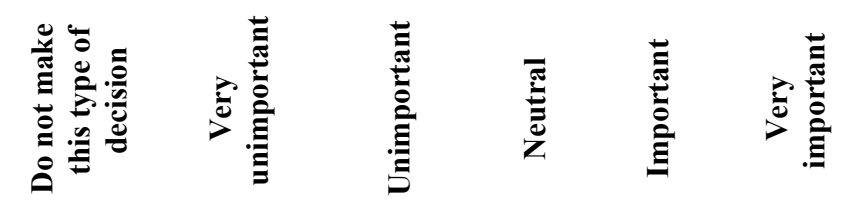

\begin{tabular}{|c|c|c|c|c|c|c|c|}
\hline a. & $\begin{array}{l}\text { Product pricing } \\
\text { decisions. }\end{array}$ & 0 & 1 & 2 & 3 & 4 & 5 \\
\hline b. & $\begin{array}{l}\text { Make or buy } \\
\text { decisions. }\end{array}$ & 0 & 1 & 2 & 3 & 4 & 5 \\
\hline c. & $\begin{array}{l}\text { Cost reduction } \\
\text { decisions. }\end{array}$ & 0 & 1 & 2 & 3 & 4 & 5 \\
\hline d. & Product mix decisions. & 0 & 1 & 2 & 3 & 4 & 5 \\
\hline e. & $\begin{array}{l}\text { Product output level } \\
\text { decisions. }\end{array}$ & 0 & 1 & 2 & 3 & 4 & 5 \\
\hline
\end{tabular}




\begin{tabular}{|c|c|c|c|c|c|c|c|}
\hline & & 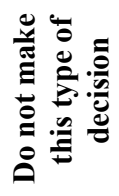 & 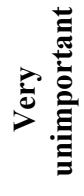 & 苛 & $\begin{array}{l}\bar{\Xi} \\
\bar{E} \\
Z\end{array}$ & 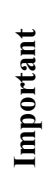 & 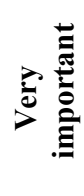 \\
\hline f. & $\begin{array}{l}\text { Product design } \\
\text { decisions. }\end{array}$ & 0 & 1 & 2 & 3 & 4 & 5 \\
\hline g. & $\begin{array}{l}\text { Evaluating new } \\
\text { production process } \\
\text { decisions. }\end{array}$ & 0 & 1 & 2 & 3 & 4 & 5 \\
\hline h. & $\begin{array}{l}\text { Product introduction } \\
\text { decisions. }\end{array}$ & 0 & 1 & 2 & 3 & 4 & 5 \\
\hline i. & $\begin{array}{l}\text { Product } \\
\text { discontinuation } \\
\text { decisions. }\end{array}$ & 0 & 1 & 2 & 3 & 4 & 5 \\
\hline
\end{tabular}

\section{Notes}

${ }^{1}$ The explanation of the forms of fit is drawn from various literature, yet it will be discussed in the context of CSD because it is the focus of this paper.

2 Besides the selection, moderation and matching forms of fit, there are the mediation and system forms of fit. Modelling the relationship between the contingency factors and $\mathrm{ABC}$ adoption as an optimal CSD from the viewpoint of the mediation form of fit entails examining the indirect effect of the contingency factor on an outcome through ABC adoption (Chenhall, 2003; 2007; Gerdin \& Greve, 2004; 2008; Gerdin, 2005a; 2005b; Hartmann, 2005; Burkert et al., 2014), while modelling it from the standpoint of the system form of fit involves examining the combined effect of multiple fits between multiple contingency factors and $\mathrm{ABC}$ adoption on an outcome (Donaldson, 2001). To the author's knowledge, the utilisation of the mediation and system forms of fit in $\mathrm{ABC}$ adoption research is limited.

${ }^{3}$ Relevant extracts from the questionnaire are included in the appendix.

${ }^{4}$ CostStructure-MANUFACTURING was transformed using square root transformation to reduce the impact of univariate outliers (Tabachnick \& Fidell, 2007; Hair et al., 2010).

${ }^{5}$ The explanation of formative constructs assumes composite-formative constructs rather than causal-formative constructs, as the former is more in line with social science research because it considers measurements to represent an approximation rather than a complete reflection of the theoretical concept (Hair et al., 2017).

${ }^{6}$ These studies have used the selection form of fit. 